\title{
The Esoteric Meaning of Culture and Language in Deciding Citizenship of Mixed Nationalities Marriage Children
}

\author{
Rudy Harjanto ${ }^{1 *} \quad$ M.S. Tumanggor ${ }^{2} \quad$ Vincentia Esti $^{2}$ \\ 1.Department of Communication, Post Graduate Program, Universitas Prof. Dr. Moestopo (Beragama), Jakarta \\ 10270, Indonesia \\ 2. Department of Law, Doctoral Program, Universitas Pelita Harapan, Jakarta 12930, Indonesia
}

\begin{abstract}
Every child has the right to have equal opportunity to grow in a safe environment, including the right of the child to acquire a balanced education about the culture of parents when both have different nationalities. This education must follow a certain period of time, and in conditions that are conducive so that children with Indonesian mothers and foreign citizen father acquire a cognitive balance, so they are able to determine the choice of citizenship when they are of legal age. This understanding will make children have a basis for adjusting to social and community norms, making it easier for them to choose which one is most comfortable for themselves in choosing their nationality when they enter adulthood
\end{abstract}

Keywords: children, different nationalities, language, culture

DOI: $10.7176 / \mathrm{JLPG} / 106-03$

Publication date: February $28^{\text {th }} 2021$

\section{Introduction}

The decision to become a citizen of children with two parents of different nationalities that needs to be made at the age of 18 years requires thoughtful consideration. Considerations which determine not only of the children own future, but also the future of their family. Decision-making processes are normative and descriptive. Normative analysis is concerned with the nature of rationality and the logic of decision making. Descriptive analysis, on the other hand, is concerning people's beliefs and preferences as they are, not as they should be. The gap between normative and descriptive considerations characterizes many studies on judgment and choice (Connolly, et al, 2000).

Any simple analysis from real life examples, of judgments and choices at least explicitly explains how far in the future decision-making thinks about the consequences of these actions, especially regarding decisions about the choice of citizenship. Decision of the nationality of the child of an Indonesian mother with a father of foreign nationality. Before a child of an Indonesian mother with a father of foreign nationality decides which nationality they want to choose, they must fully understand the culture of each of the parents. The culture of the two parents should be well understood by the child. The understanding of the cultures of different nationalities comes from the information conveyed by the two parents. This information is needed for the child to make sound decision in dealing with the situation of choosing citizenship in a much more organized and thoughtful manner, especially in adapting the culture of the two parents of different nationalities.

Edward Tylor penned that culture is "the complexity of knowledge, beliefs, arts, morals, laws, customs, and other abilities and habits acquired by humans as members of society (Tremlett, et al, 2017. Society is a group of individuals engaged in continuous social interaction which is characterized by a pattern of relationships (social relations) between individuals who share different cultures and institutions. Ethnic, regional and national differences will emphasize this difference that will shape behavioral patterns by considering certain actions or speech as acceptable or unacceptable. This phenomenon is defined as social norm. Social norms in a culture can be interpreted as the objective relations that a person has with its surrounding and with other people. Indonesian people, consisting of like-minded people governed by their own norms and values, may not necessarily accept foreign culture. Although in fact culture is static, it is open to changes that occur gradually and continuously.

Cultural studies are associated with the meaning and day to day activities, including the way language is used in communication. These practices explain why certain people in a particular culture do things. The majority of Europeans eat with knives and forks, while the majority of Indians eat with hands without cuttlery. The difference in meaning in enjoying food extends to the use of attributes to various objects and practices. People in the western world, have the view that someone who has turned 18 years old, becomes an adult and has the right to determine his own path. Meanwhile in Indonesia, a person decision making endeavor can still be heavily influenced by parents or even the grandparents. In particular, culture involves meanings and practices that are held independently of reason. It qualifies because there are no fundamental reason for one's participation in the practice of decision making

Culture is "everything that people own, think, and do as members of society." This definition can be instructive because it corresponds to the three main components of culture. That is, everything that people own refers to material property; everything that people think refers to to the things they carry in their heads, such as 
ideas, values, and attitudes; and everything people do refers to patterns of behavior. Thus, all culture is made up of material things; ideas, values and attitudes; and ways behave patterned (Tremlett, et al, 2017)

This cultural component is so closely related that it is often difficult to separate it in real life. All of this will affect the decision making for the selection of citizenship for children with parents of different nationalities. A child must have knowledge, understanding, which is in accordance with the experience, learning and comparison of the culture of both parents. This knowledge must be sufficient so that the decision to determine their nationality will be a thoughtful choice, not the influence of one of the parents.

As Indonesia lays under Dutch colonization for nearly 250 years, Indonesian legal system is heavily influenced by Dutch legal system. Indonesia law system adopts two distinct laws, the Criminal Code (KUHPidana) and the Civil Code (KUHPerdata), which are still widely used today. The preamble to the 1945 constitution confirms this in Article 1 of the transitional regulation which reads: "All existing laws and regulations are deemed to remain valid as long as a new one has not been implemented according to the 1945 constitution"

In Indonesia, based on Article 57 of Law No.1 of 1974 concerning Marriage ("UUP”) [6], what is meant by mixed nationalities (transnational) marriage is a marriage between two people in Indonesia who are subject to different laws due to different nationalities with one of the parties is an Indonesian citizen. The next article states that people who are married to transnational marriages can obtain the citizenship of their partners and may also lose their citizenship. Many children resulting from transnational marriages feel that they are tourists in Indonesia as a result of being obstructed by the Citizenship Law even though they feel they are Indonesians (Ardans, 2016)

This obstacle does not reduce the prevalence of transnational marriages. PerCaIndonesia (Indonesian Mixed Marriage Society) recorded 1,200 foreigners involved in transnational marriages. This data of transnational marriages between individuals is facilitated by the abundance of information disclosure on internet-based media, especially on social media. This information develops a common view of people of different nationalities, they build friendships, and straighten a more intensive line of introduction, which then leads to marriage. Through the prevalence of Internet, the marriage process began with introductions through social media, which then leads through physical world. This interaction through social media may also builds relationships between former work / business friends, getting acquainted while on vacation, former school / college friends, which in turn end in marriage (Artharini, 2018)

The marriage of a couple with different nationalities is subject to different laws because of different nationalities. Transnational marriages in Indonesia must meet the requirements of marriage as stated in Article 2 of Law no. 1 of 1974 concerning Marriage, namely: "(1) Marriage is legal if it is carried out according to the law of each religion and belief. (2). Every marriage is recorded according to the prevailing laws and regulations ".

Prior to this, the prospective husband or wife who has foreign citizenship must complete documentation or letters from their home country stating that they can marry an Indonesian citizen. The marriage must be reported no later than 60 days from the date of marriage to the implementing agency at the place where the marriage took place. Transnational marriages have recently grown in popularity and are separated from class differences in society.

In Indonesian law, transnational marriage is defined in Law No.1 of 1974 concerning Marriage, Article 57: "What is meant by mixed marriage in this Law is a marriage between two persons who in Indonesia are subject to different laws," because of differences in nationality and one of the parties is Indonesian citizenship ". Individuals live according to strict rules / procedures, in an effort to build / enforce general laws, based on empirical, sensory and value-free experiences.

The differing definition of nationality by each country can create citizenship problems for land ownership rights and the birth of children for couples with different nationalities. This condition explains the facts, especially in the cause-and-effect relationship of transnational marriages, which lead to predictions of difficulties in legal status regarding the desire to have land ownership rights in and clarity of child custody rights.

In short, the problem of citizenship is the emergence of confirmed citizenship status, namely whether to follow the citizenship of either parent who is a foreign citizen in Indonesia? One of the things that is certain is that an Indonesian woman who marries a foreigner will lose the basic rights of an Indonesian citizen, such as losing the right to own property in Indonesia.

This is regulated in Law No.5 of 1960 concerning Basic Agrarian Principles which states that only Indonesian citizens (WNI) can have property rights. Article 3 of PP 103/2015 [12], explains that Indonesian citizens who carry out transnational marriages with foreign citizens (WNA) can still have the same land rights as other Indonesian citizens as long as the land rights owned by Indonesian citizens and must not be shared assets.

The marriage of a couple with different nationalities also has the potential to eliminate the child's right to have Indonesian citizenship. This is regulated in Law Number 12 of 2006 concerning citizenship. Article 5 paragraph 1 states that children of Indonesian citizens who are born outside of legal marriages, are not yet 18 (eighteen) years old or have not yet been married are legally recognized by their fathers who are foreign citizens 
and are still recognized as Indonesian citizens.

In addition, this couple's marriage has the potential to eliminate the child's right to have Indonesian citizenship when the child is 18 years old and must make their choice of citizenship when they came of age. Another problem that arises as a result of this mix nationalities marriage children is the method of personal development in their daily lives towards adulthood. How to make the child from this marriage to naturally grow with both culture of the parents. So that by the time they reach 18 years old, they can determine their citizenship choice with no hesitation.

Based on this background, the problems to be studied are: How to upheld mixed nationalities marriage child's right to obtain a balanced education about the differing culture of the two parents. How to build conducive conditions so that children with Indonesian mother and foreign citizen father have a cognitive balance, to determine citizenship choices at the age of 18 .

\section{Theoretical Basis}

Law touch human life as part of everyday social life, as it is the one thing that made human unique in the living world tree of life. Law regulates human behavior or actions as members in social life. This social life requires an arrangement that contains requests, orders and prohibitions for doing something or not doing something. The law governs what individuals can and cannot do for the benefit of members of society itself. This is intended to regulate human behavior so that it does not intersect and harm the public interest. The law begins with the arrangement of the object's material.

Legal objects have general characteristics that can be distinguished from similar phenomena, and is approved as a concept (Kelsen, 2015). Legal objects are anything that is useful for legal subjects (humans and legal entities), and can become the subject / object of a legal relationship, because it can be controlled by legal subjects.

Mastery of this legal subject includes objects that can be owned and controlled by the legal subject such as vehicles, land, houses and other related concepts.

Objects according to Article 499 of the Civil Code are every item and every right, which can be controlled by property rights. Rights is also called a share of assets (vermogens bestanddeel). Assets include goods, rights and legal relationships regarding goods and rights, as regulated in book II and book III of the Civil Code. The zaak covering goods and rights is regulated in Book II of the Civil Code. Goods are tangible, while rights are intangible.

Law is also used to settle disputes, punish and govern to create an atmosphere conducive to tranquility, happiness and well-being in society. The existence of the law makes every dispute or case find a solution through a court process with an intermediary judge based on the applicable rules and regulations. The law also aims to safeguard and prevent everyone from becoming a judge of himself. The purpose of law is to provide happiness and justice based on reasons of validity in the concept of the legal order.

One of them may represent a more practical truth than the other and for that reason deserves a number of preferences. The role of knowledge does not stop giving a little more to public opinion, because the main object of its investigation is the condition of society and not social opinion (Durkheim, 2010). It is difficult to argue that social opinion contains no part of reality and that collective conscientious aspirations are only hallucinations.

The social aspiration that can be understood is that it is reality that allows the development of moral problems.

\section{Research Methodology}

This research will take form of normative law research which does not always have the connotation of juridical norm research. In general, juridical norm research is understood to be only legal research that limits existing norms in statutory regulations. Meanwhile, normative legal research is broader. This Normative Legal Research is a study that examines the study of documents, which uses a variety of secondary data such as laws and regulations, court decisions, legal theory, and it can be the opinion of academics. This type of normative research uses qualitative analysis, namely by explaining existing data in words or statements, not numbers.

The type of research used is descriptive research, which is a research that aims to obtain a complete, detailed, clear, and systematic description of several aspects studied in laws or regional regulations or contract texts or other objects of study. The research method used the hermeneutic phenomenology approach.

Hermeneutic phenomenology approach is one type of qualitative research method that is applied to reveal the similarity of meaning which is the essence of a phenomenon that is consciously and individually experienced by a group of individuals in their life. Matters studied in this research include several things such as legal principles, legal systematics and personal experience.

Personal experience is the main source of information. Combined with other data sources, including normative legal research and laws and regulations related to cases to acquire justice. Absolute justice on the other hand, implants the idea of justice, as it is usually understood, more directly into its core fundamentals. This conception relies less on general facts in achieving compatibility with our judges. This ensures that it fits a wide 
range of possible cases (Rawls, 1999)

This research is a collection and analysis of legal data and information about the rights of Indonesian mothers of children in transnational marriages. The collection of data and information was carried out through literature study coupled with a process of observing Indonesian women who married foreign nationals. The research paradigm used is hermeneutics, which is the method used to interpret the world through text. For this reason, researchers conduct library studies, meaning reconstructions, physical background explanations, special incident reports, and observation activities - and reflective notes - which are opportunities for researchers to: record personal thoughts such as speculation, feelings, problems, ideas, hunches, impressions, and prejudice (Bogdan, Biklen, 2007)

The method used is intended so that researchers can develop a literature review and then strengthen it with the results of dialogue reconstruction, explanations of physical settings, reports of special events, activities and reflective notes - opportunities for researchers to; records personal thoughts such as speculations, feelings, problems, ideas, hunches, impressions, and prejudices. Researchers will place themselves fully in a position to determine the completion of interpretation based on inductive thinking patterns.

According to Johnny Ibrahim (2005), normative legal research is a scientific research procedure to find truth based on scientific logic from the normative side. The normative side here is not limited to statutory regulations.

The main source experience is explored to obtain a fundamental and comprehensive picture as a reflective structural analysis to summarize the essence of the discussion. This research is designed to get an overview of the life experiences of individuals who experience a phenomenon as described by the participants (Creswell, 2014).

The data in this study were processed using inductive methods and qualitative approaches. The purpose of this research is to reveal facts, circumstances, phenomena, variables and circumstances that occur when the research is running and present it as it is. This qualitative research will interpret and tell the data related to the current situation, attitudes and views that occur in interpreting the phenomenon.

\section{Discussion}

An Indonesian woman who marries a foreigner will lose the basic rights of an Indonesian citizen, such as losing the right to own property in Indonesia. This is regulated in Law No.5 of 1960 on Basic Agrarian Principles which states that only Indonesian citizens (WNI) can have property rights. Article 3 of PP 103/2015 [22], explains that Indonesian citizens who carry out mixed nationalities marriages with foreign citizens (WNA) can still have the same land rights as other Indonesian citizens as long as the land rights owned by the Indonesian citizen must not be shared assets.

The marriage of a couple with different nationalities has the potential to eliminate the child's right to have Indonesian citizenship. This is regulated in Law Number 12 of 2006 concerning citizenship, article 5 paragraph 1 states that children of Indonesian citizens who are born out of legal marriages, are not yet 18 (eighteen) years old or have not yet been married are legally recognized by their fathers who are foreign citizens, are still recognized as Indonesian citizens.

The peculiar issue facing children of transnational marriage is the method of personal development of children in their daily lives until they are 18, when it is required them to choose one of the nationalities of his father or mother. How to educate and broaden the cultural insight of the two parents from different countries so that the child of this marriage grows naturally without hesitating to choose a different nationality from the two parents. The choice of citizenship should be made after the child understands the cognitive, affective, and behavior about each nation and country from both parents. So that by the time they are 18 years old, they can consciously and purposefully determine their citizenship choice.

Early in a child's life is the most appropriate time to provide encouragement or development efforts so that children can develop optimally. The Law Number 20 of 2003 concerning the National Education System Chapter I Article 1 point 14 states that Indonesia early childhood education and development (PAUD) is an effort of character building aimed at children. Law Number 20 of 2003 states explicitly in the National Education System, that education will start at an early age, so it is no longer during school age. It is further stated in the law (Chapter I, article 1, point 14) that early childhood education is a coaching effort aimed at children from birth to six years of age carried out by providing educational stimuli to assist physical and spiritual growth of children to prepare them for proper tiered education. Early childhood education is the most basic education that occupies a strategic position in the development of human resources. Early childhood education is held before basic education, and many countries pay great attention to the implementation of early childhood education. The reasoning is simply because that children's mind when young are quite malleable and easier to be teached compared when the child has grown older and have a mind of their own.

In Indonesia, according to article 28 of Law Number 20 of 2003 concerning the National Education System, early childhood education has been placed equal to other education. Even at the peak of the commemoration of 
National Children's Day on July 23, 2003, the President of the Republic of Indonesia has launched the implementation of early childhood education throughout Indonesia in the best interests of Indonesian children. Indonesian children have rights that should be obtained by each child based on the convention of children's rights. In 1954, the United Nations (UN) announced the rights of children. Then in 1989, it was passed as a convention on children's rights.

Indonesia government, through Presidential Decree no. 36 of 1990 recognizes the rights of these children, which include and are not limited to: the right to play which gives children a way to learn. Through playing, children learn about the world around them. In addition, playing also has many positive benefits for children, especially when done with peers and / or with parents. Children interactivity with things and people allows them to expand their creativity and critical thinking, therefore the government recognizes that children should be allowed to expand their mind since early age, with proper structured guidance from early learning teachings.

Every child has the right to get a proper education. If there are families who are economically incapable of sending their children to school, the government through Law Number 23 of 2002 concerning Child Protection, especially article 53, that the government is responsible for providing assistance or free assistance for children from poor families, neglected children, and children who live in remote areas.

Education is the most important and foremost thing in our life. Everyone has the right to education, which in this matter has been stated in article 31 of the 1945 Constitution. Therefore, no one can prevent people from pursuing the highest education possible in Indonesia. Many opinions from philosophers, about the meaning of education, whether it is necessary to put so much effort into one aspect of governing for country to focus on as mostly tiered education is still debatable if it can produce a proper person that functions in society. This critical thinking comes from the many anecdotal evidence of people who did white collar crimes, embezzling money through advance know how of the financial system or just simple petty theft from people with graduate degrees. However, broadly speaking education is a conscious effort to develop personality and abilities inside and outside formal education and lasts a lifetime. The education people receive is not only formal education, but also informal education and non-formal education.

Indonesia government amended the Child Protection Law in 2014 to strengthen its position for children protection in Indonesia. This law, number 35 of 2014 concerning Amendments to Law Number 23 of 2002 concerning Child Protection. The amendment to the Law on Child Protection is due to the reason that in order to increase protection for children it is necessary to make adjustments to several provisions in Law Number 23 of 2002 concerning Child Protection. Article 6, for example, states that every child has the right to worship according to his / her religion, think and express himself according to the level of intelligence and age under the guidance of a parent or guardian.

In the Convention on the Right of the Child (CRC), which has been ratified by the Indonesian government with Presidential Decree No. 36 of 1990, contains four general principles regarding children's rights, namely: 1) That children are provided with rights without exception. 2) That children have the right to live and develop. 3) That the interests of children should be the main consideration in all decisions or actions affecting the child. 4) That children are allowed to participate as active participants in everything that affects their lives.

Actively participating in all things that affect oneself means adopting a living culture, being shared by a group of people, and passed down from generation to generation. The culture is made up of many complex elements, including language. Language, like culture, is such an inseparable part of human being that many people tend to think of it as being genetically inherited. In life, this notion could not be more further than the truth as culture is passed down from generation to generation from teachings through elder generation to younger generation. Many cultures are famous for speaking loudly in regular speaking condition, and although to to them it sounds normal, to other culture, it is considered rude. This speaking loudly is a passed down trait as people from the same culture if living in an area that in majority speaks slowly, they too will talk slowly.

When someone tries to communicate with people of different cultures, and adjusts their differences, it proves that culture can be learned. Culture can be considered as part of the environment that is in essence, a human creation (Kluckhohn, 2018). Sometimes intelligent common sense has an answer akin to that of anthropologists: "because they were raised that way." What is meant by "cultural" anthropology means the total lifestyle of a nation, the social heritage that individuals get from their group.

Children deserve the opportunity to continue to develop in order to achieve long-term success. The main objective of this long-term development is to create a safe environment in which children can learn freely, that is, without using force or coercion, attracting children's curiosity to lead their own learning.

Children learn to be structured by making them learn to voice their opinions. The opinions of the children cover many things, including criticism of culturally different ways of life. This condition allows every time a child feels that their rights have been violated by others, they can voice it to both parents at any time to resolve the conflict immediately.

The role of the child is to learn, with the hope of following his own interests. In addition, children are expected to become responsible members of society, follow community rules or face consequences. The role of 
parents varies from family to family. In some culture, parents offer knowledge for those who want to know it, in other families, parents are careful when teaching until the child asks for lessons. These two stark contrast is one example of difference of culture transnational marriage children may experience.

Although parents tends to be considered as the authoritarian figure that often use of unnecessary authority and coercion to educate children, parents often act as good mannered teachers, in that they will try to be involved in daily educational activities at home. Now parents are all teachers helping to navigate the culture to their children in a conducive and comfortable way.

Cultural navigation will make every child entitled to get a name or identity to be used as part of their identity and recorded in state documents. This right is closely related to the next right, namely the right to have citizenship. Every child has the right to obtain national status, which means that his citizenship is officially recognized by a nation through the issuance of citizenship documents, which include birth certificates and identity cards.

These documents are important to guarantee children's rights to education, adequate health services, and socio-political rights during general elections. The State strives to respect the rights of children to maintain their identity, including nationality, name and family relations as recognized by law without illegal interference. An identity if it is not introduced from the beginning will certainly result in something that devastates the identity itself. Like culture, the more children encounter foreign cultures in their surroundings, it will be a tough task for parents.

This national identity includes the role of their language in life. This language is important for these children, especially to maintain ties with their families and communities. Language is the guardian of children's identity as members of their family and community (Mills, 2001). Thus, language becomes an important contributor to community and national identity for children, especially those with parents of different nationalities.

So it is clear that learning language does not only involve personal abilities in social interaction in the community, but also the need for awareness of how identity is linked to sociocultural activities. The family as part of the community is not just a neat and independent mini-society, isolated from the outside world but an integral part of the wider society. As part of civic life, there is a need for further exploration and reflection on how to develop and organize educational methods to help children with the complex problems they face inside and outside their communities.

Parents who want their children to become citizens of a particular country should engage in self-reflection and examine the basis and experience of teaching about their own language and cultural biases (Lee, 2003) [36]. Teaching materials must contain certain national culture and knowledge to instill a sense of pride in a certain culture and national identity. Pride in culture and identity shows the inseparable relationship between language, culture and identity. Personal identities are woven into complex dimensions of: own cultural values, sociocultural context, and language ideology.

Cultural values in children need to be developed so that they become humans who have aesthetic sensitivity. Along with their physical and psychological growth, children need to be taught aesthetics through arts and culture. Every child has the potential to have extraordinary creative power. The inculcation of character and character values in children is an important asset in developing their self-confidence in fostering and developing arts that are aligned with national identity and character.

During their infancy, transnational marriage children received cultural-related lessons from their parents with different nationalities. So that they are not isolated from their cultural roots following the rapid development of technology. Various activities can be programmed for children to get to know the cultural roots of these different countries. Children need to be introduced to art and culture from an early age, intended to instill aesthetic characters. As well as providing entertainment that is healthy, educative, and has cultural value to the children of their parents.

Forming an aesthetic character can be started from loving the arts and culture of a certain country, so that the child knows the arts and culture of the country of birth of the two parents. Because by loving the country's art and culture, children will develop these characters more quickly. Regional culture, including traditional arts, in addition to fostering children's creativity, also fosters the desire to preserve local wisdom. So that children need to be introduced to various sources of local art and culture in developing aesthetic characters.

The children of mixed marriages will know very well the various cultural sources in the area of their two parents. In each country, the father and mother of the child will each know local dance, legends, history, traditional children's games or fairy tales related to their respective regional traditions. This understanding will lead children to the orientation of which cultural conditions they are most comfortable with, which will make it easier for them to make decisions about which country to choose when the time to choose their citizenship comes.

This orientation toward the most compatible culture affirms that society is made up of individual parts, and thus individual characters can be formed separately. Each particular culture is a kind of blueprint for all life's 
activities. (Kluckhohn, 2018). The formation of individual character is a process of parents to spread knowledge, beliefs, values that children accept to be applied in society. Children are recipients of information, and learning is the process of memorizing information or acquiring skills. This orientation is mainly related to establishing the basis for choosing citizenship.

The choice of citizenship is subjective, because a father or a mother tends to get along easily with their children. Father and mother try to communicate and apply the culture of origin which is expressed through cognitive insights. As a result, if one of the two parents is dominant, then the culture of this dominant party will tend to be applied to the child as knowledge, direction of attitudes and leads to behavior. Children who are still innocent will be affected, and finally make their choice because of the influence of one of the dominant parties. This is unfair, because the passive parent is helpless, and becomes a "silent partner", in the sense that being an individual does not reveal what he wants.

The basis for selecting citizenship requires a solid foundation. The basis for a balance of insight into cognitive insights about each of these different countries. Each child will determine the quality of human resources in the future, as well as the generation that will become the nation's successor. They must be prepared and directed from an early age so that they can grow and develop into children who are physically and mentally healthy, advanced, independent and prosperous into quality resources and can face challenges in the future.

Early in a child's life is the most appropriate time to provide encouragement or development efforts so that children can develop optimally. There by, the authority needs to create a relevant regulation to support this notion. This institution should require the parents of different nationalities to provide certain and adequate time to provide education to their children so periodic education is carried out with a minimum of a certain time so that children can have the time to absorb the educational material. Material for a balanced understanding of each country to their children in a conducive atmosphere, with neither party is dominant or forcing their view that the culture of one parent is superior than the other. The main basic materials are language and culture, as this basic teaching material is an effort to develop the child's personality and abilities, so that they get a balanced picture of which country they will choose later.

\section{Conclusion}

Every child, has the right to have the same opportunity to grow and develop. The right of the child to obtain a balanced education about the culture and language of the two parents of different nationalities must be respected. This education must run within a certain period of time, and in conditions that are conducive so that children with Indonesian mothers and foreign citizen father have a cognitive balance, to determine their choice of citizenship when they have come of age. Children have the right to get the same understanding of culture, language, from both parents of different nationalities. This understanding will make children have a basis for adjusting to social and community norms, making it easier for them to choose which one is most comfortable for themselves in choosing their nationality.

For this reason, it is necessary to have regulations from the authority institution to regulate a certain balance of time and material for both parents. Both parents provide a balance of attention and sufficient time for development and objective orientation. This balance of knowledge will solidify the choice of nationality at the age of 18 .

\section{References}

Ardans, Busrah, 2018. Jadi Tren, PerCa Catat 1.200 Orang WNA Terlibat Pernikahan Campur. Tribun Bali, Minggu, 15 April 2018 12:00, downloaded $20 \quad$ Februari $2020 \quad 11: 45 \quad$ pm https://bali.tribunnews.com/2018/04/15/jadi-tren-perca-catat-1200-orang-wna-terlibat-pernikahan-campur.

Artharini, Isyana, 2016. Problematika di balik kewarganegaraan ganda. BBC News Indonesia 18 Agustus 2016 downloaded 20 Februari 2020 11:05 pm

Bogdan, Robert C., Sari Knopp Biklen, 2007. Qualitative Research for Education. An Introduction to Theory and Methods 5th edition. Boston, MA: Allyn and Bacon

Convention on the Right of the Child (CRC), which has been ratified by the Indonesian government with Presidential Decree No. 36 of 1990,

Connolly, Terry, Hal R. Arkes, Kenneth R. Hammond, 2000. Judgment and decision making: an interdisciplinary reader Rev. ed. Cambridge, United Kingdom: The Press Syndicate of The University of Cambridge.

Creswell, John W., 2014. Qualitative Inquiry\& Research Design. Choosing Among Five Approaches. Thousand Oaks, California: Sage Publications, Inc.

Durkheim, Emile , 2010. Sociology and Philosophy Translated by D. F. Pocock with an Introduction by J.G. Peristiany. Abingdon, Oxon: Routledge

Ibrahim, Johnny, 2005. Teori dan metode penelitian hukum normatif. Malang : Bayumedia Publishing

Kelsen, Hans, 2015. Teori Hukum Murni. Dasar-dasar Ilmu Hukum Normatif cetakan XV. Pure Theory of Law, 
translated: Raisul Muttaqien. Bandung: Nusa Media

Kluckhohn. Clyde, 2018. Mirror For Man. The Relation of Anthropology to Modern Life. New York: Routledge Lee, Su Kim, 2003. Exploring the Relationship between Language, Culture and Identity

Mills, Jean, 2001. Being Bilingual: Perspectives of Third Generation Asian Children on Language, Culture and Identity, International Journal of Bilingual Education and Bilingualism, 4:6, 383402, DOI: $10.1080 / 13670050108667739$

Law Number 23 of 2002 concerning Child Protection, article 53

Rawls, John, 1999. A Theory of Justice. Cambridge, Massachusetts: The Belknap Press of Harvard University Press

The 1945 Constitution, article 31

The Child Protection Law in 2014

The Civil Code (Kitab Undang -undang Hukum Perdata)

The Civil Code, article 499

The Criminal Code (Kitab Undang -undang Hukum Pidana)

The Law of Mariage No.1 of 1974, article 57 ("UUP"- Undang-undang Perkawinan)

The Law of Mariage No.1 of 1974, article 2 ("UUP"- Undang-undang Perkawinan)

The Law of Mariage No.1 of 1974, article 57 ("UUP"- Undang-undang Perkawinan)

The Law No.5 of 1960 concerning Basic Agrarian Principles

The Law No.5 of 1960 concerning Basic Agrarian Principles Article 3 of PP 103/2015

The Law Number 12 of 2006 concerning citizenship. Article 5 paragraph 1

The Law No.5 of 1960 on Basic Agrarian Principles

The Law No.5 of 1960 on Basic Agrarian Principles, article 3 of PP 103/2015,

The Law Number 12 of 2006 concerning citizenship. Article 5 paragraph 1

The Law Number 20 of 2003 the National Education System Chapter I Article 1 point 14

The Law Number 20 of 2003, Chapter I, article 1, point 14)

The Law, number 35 of 2014 concerning Amendments to Law Number 23 of 2002 [28]

The Law Number 23 of 2002 concerning Child Protection, article 6

United Nations (UN) 1954. The Rights of Children

Tremlett, Paul-François, Liam T. Sutherland and Graham Harvey (Eds.), 2017. Edward Burnett Tylor, Religion and Culture. London: Bloomsbury Academic. An imprint of Bloomsbury Publishing Plc

Presidential Decree no. 36 of 1990 